\title{
Microbiological Indicators of the Quality of River Water, Used for Drinking Water Supply
}

\author{
Łukasz Augustyn ${ }^{1,2 *}$, Anna Babula ${ }^{2}$, Jolanta Joniec ${ }^{3}$, Jadwiga Stanek-Tarkowska ${ }^{1}$, \\ Edmund Hajduk ${ }^{1}$, Janina Kaniuczak ${ }^{1}$
}

${ }^{1}$ Soil Science, Environmental Chemistry and Hydrology Department, Biology and Agriculture Faculty, University of Rzeszow, Zelwerowicza 8B, 35-601 Rzeszow

${ }^{2}$ District Sanitary and Epidemiological Station in Mielec,

Marii Skłodowskiej-Curie 8 st., 39-300 Mielec ${ }^{3}$ Environmental Microbiology Department, University of Nature in Lublin,

Leszczynski 7, 20-069 Lublin

Received: 8 September 2015

Accepted: 1 December 2015

\begin{abstract}
Pathogenic microorganisms are a common component of surface water reaching rivers along with sewage. If present in small quantities, they are not a threat to the health and life of humans, but in larger quantities can be a pathogenic factor causing much discomfort. The amount of pathogenic bacteria in river waters varies depending on various factors such as the size of the stream, the season, water level, degree of eutrophication of the watercourse and its tributaries, or geographical area through which the river flows and the ability of a watercourse to self-clean. In view of the risks that may be caused by microorganisms pathogenic to humans and animals, a constant monitoring of their quantity in surface waters has been carried out. As follows from studies conducted for the past several years (1999-2010), the number of coliforms and thermo-tolerant coliforms in Wisłoka River water near Mielec showed a downward trend, while that of fecal enterococci (Enterococcus faecalis) a growing tendency. At that time there was no evidence of Salmonella. In almost the whole study period, pollution of human origin exerted a major impact on the sanitary conditions of tested water. Only in 2006 were they of the zoonotic nature. Analyzed sanitation parameters of surface water in the Wisłoka River collected in a water intake point for the city of Mielec showed high variability, depending on the season and water $\mathrm{pH}$. Coliform bacteria showed the highest number at the lowest $\mathrm{pH}(\leq 7.0)$. There was very high, positive correlation $\left(\mathrm{r}_{x, y}>0.7\right)$ between the number of microorganisms and selected physicochemical indicators of water quality. Count of coliform bacteria and
\end{abstract}

*e-mail: augustynlukasz@wp.pl 
thermo-tolerant coliform type increased along with the increase in the value of electrolytic conductivity. The largest correlation $\left(r_{x, y}=0.85\right)$ was recorded between the number of fecal enterococci and the level of $\mathrm{BOD}_{5}$ indicator.

Keywords: surface water, coliforms, thermo-tolerant (fecal) coliform type, fecal enterococci (Enterococcus faecalis), physicochemical parameters, correlation

\section{Introduction}

In addition to the native (indigenous) microflora, the river waters also contain allochthonic microorganisms that can be potentially harmful to the health and life of humans. For hygienic-sanitary safety reasons, the amount of this type of microorganisms found in river waters is constantly monitored, especially in cases when the river water is used for human consumption [1-8]. Many authors have demonstrated that agricultural or urban pressures are highly associated with loading of Salmonella and other enteric bacteria in the surface waters. However, natural factors also may be relevant to, e.g., precipitation, or birds can be a source of microbiological contamination $[9,10]$. The surface water is a reservoir of a spectrum of pathogenic microorganisms, including coliforms, thermotolerant coliform bacteria, Enterococcus faecalis, and Salmonella [9, 11-16]. All these bacteria are referred to as sewage bacteria that deserve special attention. As intestinal bacteria, a special pathogenic feature is exhibited by gram-negative Salmonella, including those that cause typhoid. Elevated concentrations of sewage bacteria is a potential threat to human health in the case of sewage penetration into the environment $[5,17]$. Therefore, the occurrence of all above-mentioned bacteria in the water may be indicative of "fresh" water pollution with sewage $[15,18]$. These microorganisms can cause many problems, among which are: fever, diarrhea, nausea, vomiting, and in extreme cases they can lead to death [19].

Surface water quality, due to microbiological indicators, is of great importance for the economy, because there are legal standards governing their monitoring and protection (Directive 75/440/EWG, Reg. Min. Environ. ... 2002 and Water Law, [3, 20, 21]).

The aim of our study is to assess the amount of coliform bacteria, thermo-tolerant (fecal) coliform bacteria, fecal enterococci (Enterococcus faecalis), and Salmonella in the surface waters of the Wisłoka River for supplying the population of Mielec in drinking water. Also an attempt to look for correlation between the selected physicochemical variables of water quality and quantitative occurrence of tested bacterial groups in these waters was undertaken.

The present studies are part of a wide body of work dedicated to the water quality of the Wisłoka River in the area of the city of Mielec.

\section{Material and Methods}

\section{Area of Study}

The water supply system in Mielec uses the waters of the Wisłoka from an unshielded side water intake. The Wisłoka flows through Podkarpacie Province from south to north, and its catchment covers an area of more than $4,100 \mathrm{~km}^{2}$. Wisłoka springs are located in the macroregion Central Beskidy and mesoregion Beskid Niski (Magurski National Park and Jaśliski Landscape Park). More recently, intensive agricultural and breeding activity was conducted in the cover of the protected areas, which have since been discontinued $[1,22]$. Below Beskid Niski, the Wisłoka flows into the Pogórze Środkowo-beskidzkie - areas with a high degree of the natural environment conversion caused by agriculture. Below Pilzno, the Wisłoka enters the Kotlina Sandomierska, where around Mielec it flows into the Vistula River $\left(50^{\circ} 26^{\prime} 17^{\prime \prime} \mathrm{N}\right.$ and $\left.21^{\circ} 23^{\prime} 07^{\prime \prime} \mathrm{E}\right)$ [1].

The side water intake for Mielec is located near Wojsławska Street in Mielec. The actual efficiency of the intake is $9,680 \mathrm{~m}^{3} /$ day, and it is less than $25 \%$ of the production capacity of the water treatment plant (WTP), resulting from the authorization [22].

\section{Sampling and Study Methods}

The study results upon the occurrence of selected pathogenic bacteria referred to the following years: coliform, 1999-2010 (129 tests); thermo-tolerant coliform type, 2003-2010 (85 tests); fecal enterococci, 2003-10 (85 tests); and Salmonella, 2005-10 (59 tests). The assays were carried out in the frame of the screening by the District Sanitary and Epidemiological Station in Mielec. Water samples were collected according to the control procedure $\mathrm{PK} / \mathrm{PP} / 01$ Collecting samples for tests in the frame of a current supervision and control instruction IK/ $\mathrm{PP} / \mathrm{SK} / 01 / 01$ Collecting the water samples for physical, chemical, and biological tests (predominantly in the first week of each month in two repeats), based on the following standards:

- PN-EN ISO 5667-3:2005, Water quality. Sampling. Part 3. Preservation and handling of water samples.

- PN-EN ISO/IEC 17020:2006/Ap1:2007, General criteria for the operation of various types of bodies performing inspection. 
All tests were performed in a certified Laboratory of Environmental Hygiene (Certificate No: AB 695), acting on the basis of standard PN-EN ISO/IEC 17025:2005/ AC:2007, General requirements for the competence of testing and calibration laboratories:

- Coliforms: PN-75/C-04615.05. Water and sewage. Microbiological assays. Determination of coliform bacteria by means of tube fermentation method.

- Thermo-tolerant coliform type: PN-77/C-04615.07. Water and sewage. Microbiological assays. Determination of fecal coliform bacteria by means of tube fermentation method.

- Fecal enterococci: PN-EN ISO 7899-2:2004 Water quality. Detection and enumeration of intestinal enterococci. Part 2. Membrane filtration method.

- Salmonella bacteria: PB/PHK-01 Detection and isolation of Salmonella in waters (procedure of PSSE Mielec).

\section{Assessment of Results}

The test results were evaluated by taking into account average occurrence for annual and multi-year, as well as depending on the season and the $\mathrm{pH}$ values of water. The results were statistically processed by calculating mean values, correlations, and LSD by Tukey at the significance level of $p=0.05$. Results of microorganism presence in Wisłoka water at the surface water intake point for Mielec were compared, taking into account the requirements of Reg. Min. Environ. from 2002, which lists three categories of water quality (A1, A2, A3) depending on the limits of indicators [21]:

- A1 - water requiring simple physical treatment, in particular by filtration and disinfection;

- A2 - water requiring typical physical and chemical treatment, in particular of pre-oxidation, coagulation, flocculation, decantation, filtration, and disinfection (final chlorination);

- A3 - water requiring high-efficiency physical and chemical treatment, particularly oxidation, coagulation, flocculation, decantation, filtration, adsorption on activated charcoal, and disinfection (ozonation, final chlorination) [21].
Also, the attempt to search for correlations between selected physicochemical factors characterizing the water samples analyzed and described in [1] vs. number of specific microorganisms was undertaken (the same water samples). Simple correlation Pearson coefficients $r_{x, y}$ were calculated, assuming the defined physicochemical parameter of water as variable $\mathrm{x}$, and the number of microorganisms as variable $y$. On the basis of thermotolerant coliform bacteria number to the number of Enterococcus faecalis ratio, an assessment of the origin of water pollution in the Wisłoka (from human or animal waste) was carried out in every research year.

The number of studied microbiological parameters in the surface water monitoring of the Wisłoka near Mielec resulted from applicable laws as well as the test abilities of the District Sanitary-Epidemiological Station in Mielec. Therefore, some of the analyzed parameters were included, while others were excluded from the scope of testing in the analyzed period. Sampling was generally based on the annual work plan, which was subject to slight modifications depending on hydrological conditions in the watercourses, which was the subject of the present study. The sampling did not include periods of sudden spates.

\section{Results and Discussion}

Selected microbiological indicators in Wisłoka waters coming from the intake for Mielec, along with statistical parameters, are shown in Table 1.

During the study period, the most variable results characterized the thermo-tolerant coliform type of bacteria, much less the coliforms, while the least characterized the fecal enterococci. The bacteria amount in the study period was declining for coliforms and thermo-tolerant coliform, whereas it was growing for fecal enterococci (Table 1). The level of contamination of the lower section of the Wisłoka (around Mielec) is mainly determined by urban and industrial pollution (chemical and agri-food industry), discharged from Mielec and cities located upstream. A significant contribution to the pollution of water in this region also accounts for agriculture [3, 22]. Probably

Table 1. The chosen microbiological indicators in Wisłoka River waters coming from the intake for Mielec with statistical parameters.

\begin{tabular}{|c|c|c|c|c|}
\hline \multirow{2}{*}{ No. } & Specification & Coliform bacteria & Fecal coliform bacteria & Enterococcus faecalis \\
\cline { 2 - 5 } & Unit & $*$ MPN $100 \mathrm{~cm}^{-3}$ & MPN·100 $\mathrm{cm}^{-3}$ & $* * \mathrm{cfu} \cdot 100 \mathrm{~cm}^{-3}$ \\
\hline 2 & Minimum & 37 & 13 & 29 \\
\hline 3 & Maximum & 70000 & 24000 & 210 \\
\hline 4 & Average & 16140 & 9081 & 51 \\
\hline 5 & Standard deviation & 19099 & 151.1 & 46.7 \\
\hline 6 & Trend of population during the study period & 118.3 & decrease & increase \\
\hline
\end{tabular}




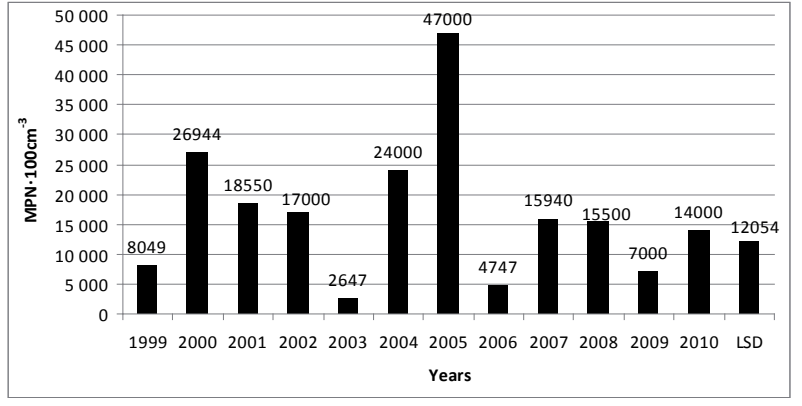

Fig. 1. The medium MPN (most probable number) of coliform bacteria in 1999-2010.

sewage from households has some remarkable impact on microbiological status of waters. The research by Grave and Weaver [4, 13] shows that numerous pathogenic and potentially pathogenic microorganisms are recorded in the wastewater from households. Microbiological indicators of surface water quality affect the classification of Wisłoka waters. Despite the improving chemical and physicochemical parameters of water quality [1, 23], microbiological indicators can still be a cause of lowerquality Wisłoka surface waters [24].

\section{Coliform Bacteria}

In the analyzed period the number of coliform bacteria in Wisłoka surface waters near the water intake for Mielec showed a large variation. The lowest average MPN of coliform bacteria was found in 2003 at 2,647 MPN·100 $\mathrm{cm}^{-3}$, while the highest in 2005 was $47,000 \mathrm{MPN} \cdot 100$ $\mathrm{cm}^{-3}$, which is almost 18 times more than in the year characterized by the lowest mean population (Fig. 1).

The average MPN bacteria in the studied period amounted to 16,140 MPN $100 \mathrm{~cm}^{-3}$ (Table 1). According to Skonieczek [25], in recent years, microbiological indicators most commonly affected the surface water exclusion of categorization as defined in Reg. Min. Environ. from 2002 [21]. Some results of MPN bacteria from 1999-2002 and 2005 were outside the acceptable limit of bacterial numbers for A3 water category (more

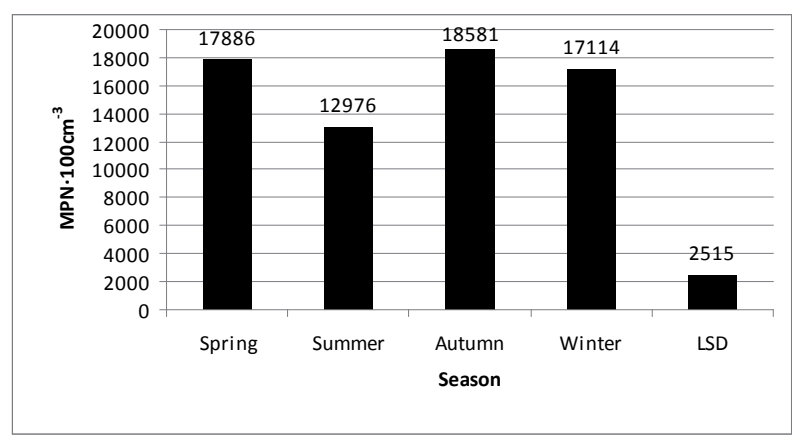

Fig. 2. The medium MPN of coliform bacteria depending on the season in 1999-2010. than 50,000 MPN·100 $\mathrm{cm}^{-3}$ ), which excluded Wisłoka waters at the studied water intake from their utilization for consumption purposes that time.

The analysis of coliforms, depending on the season, showed their greatest number in the fall, a little less in spring and winter, and significantly the lowest in summer. These quantities ranged from 12,976 MPN $100 \mathrm{~cm}^{-3}$ in the summer season to $18,581 \mathrm{MPN} 100 \mathrm{~cm}^{-3}$ in autumn (Fig. 2). Also, Delpha and Rodriguez [2] and Fonseca et al. [26] observed the lowest amount of fecal coliforms in river water in summer months. Some authors [27] reported a significantly lower number of coliforms in winter than in autumn. According to Grabińska [28], the largest nitrogen contents, as a eutrophicating factor, appear in rivers during the spring thaw and autumn rains, which favor the growth of microorganisms and which are reflected in the obtained test results. These assumptions were also confirmed by Kaniuczak and Augustyn [23] in studies upon the content of organic nitrogen in Wisłoka water in particular seasons. The authors recorded the highest content of this component in the fall, and the lowest in summer. Kadir and Nelson [29] found that E. coli inactivation depends strongly on dissolved oxygen concentration and the presence of UVB radiation, which can be related to seasonal variation number of bacteria. During monsoon season most of the spring water samples contained a higher content of coliform bacteria, which was proven by Hema et al. [30]. Rainwater may move microbial pollutants through a watershed, where they collect and drain into rivers, but may also be diluted.

The number of coliforms in Wisłoka surface water varied depending on $\mathrm{pH}$ value (Fig. 3). Their largest quantity - over 25,000 MPN·100 $\mathrm{cm}^{-3}$ - was found below $\mathrm{pH}$ 7.0. The lowest amount was recorded within the $\mathrm{pH}$ range of 7.1-7.5 (13,521 MPN·100 $\left.\mathrm{cm}^{-3}\right)$; this value gradually increased in subsequent ranges of $\mathrm{pH}$ to reach the limit range of $\mathrm{pH} \geq 8.1$ value of $17,200 \mathrm{MPN} \cdot 100 \mathrm{~cm}^{-3}$. Only mean MPN of coliform bacteria within the range below $\mathrm{pH} 7.0$ statistically differed from results in other $\mathrm{pH}$ ranges $(\mathrm{p}=0.05)$.

Coliform bacteria are gram-negative rods capable of performing the fermentation of lactose to form acidic products [12]. Therefore, the large cell frequency of this

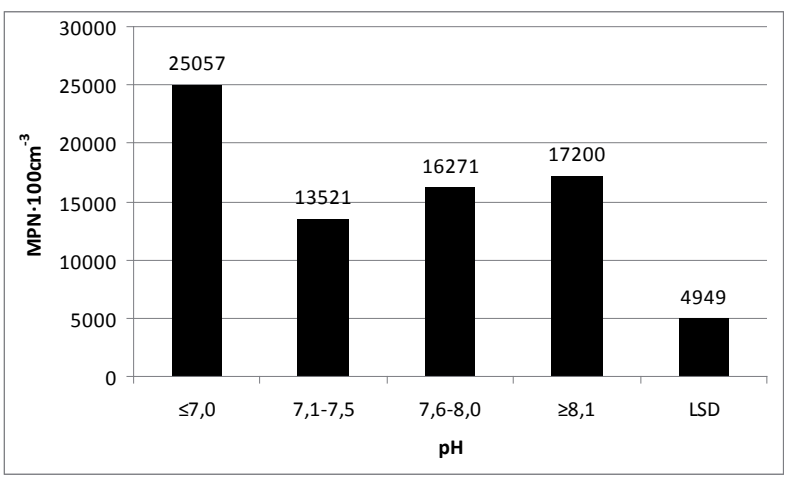

Fig. 3. The medium MPN of coliform bacteria depending on the $\mathrm{pH}$ value in 1999-2010. 


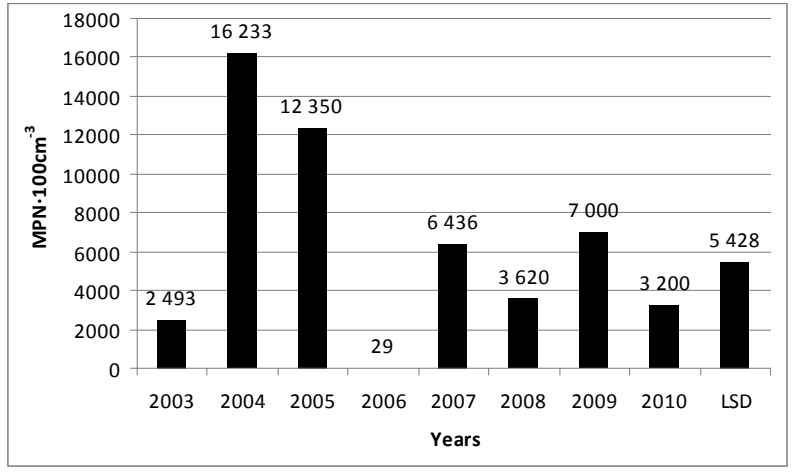

Fig. 4. The medium MPN of fecal coliform bacteria in 2003-10.

group of microorganisms in water of $\mathrm{pH} \leq 7.0$ demonstrated in this study resulted from the fact that optimum $\mathrm{pH}$ for the growth of these bacteria is 6-7.

\section{Thermo-Tolerant (Fecal) Coliform Type}

The number of thermo-tolerant coliforms, like that of coliforms, changed and showed a decreased trend over the period considered (Fig. 4). The lowest average number of these microorganisms was found in 2006 (29 MPN $\left.100 \mathrm{~cm}^{-3}\right)$, and the highest in 2004 (16,233 MPN $100 \mathrm{~cm}^{-3}$ ). Considering all the results of analysis, the number of thermo-tolerant coliform bacteria during the study period ranged from 13 MPN $100 \mathrm{~cm}^{-3}$ (summer of 2006) up to 24,000 MPN $100 \mathrm{~cm}^{-3}$ (in the spring 2005 and 2006). The average number of thermo-tolerant coliforms was 6,081 MPN $100 \mathrm{~cm}^{-3}$ (Table 1), which corresponds to the A3 category of surface water quality criteria defined in Reg. Min. Environ. from 2002, due to the limit and recommended amount of microorganisms in this type of water [21]. However, during the study period, there were water samples that did not meet the requirements set out in the Regulation, these were the results of analyzes obtained in June 2004, April 2005, September 2007, and October 2009.

Analysis of the study results upon the occurrence of thermo-tolerant coliform, depending on the season,

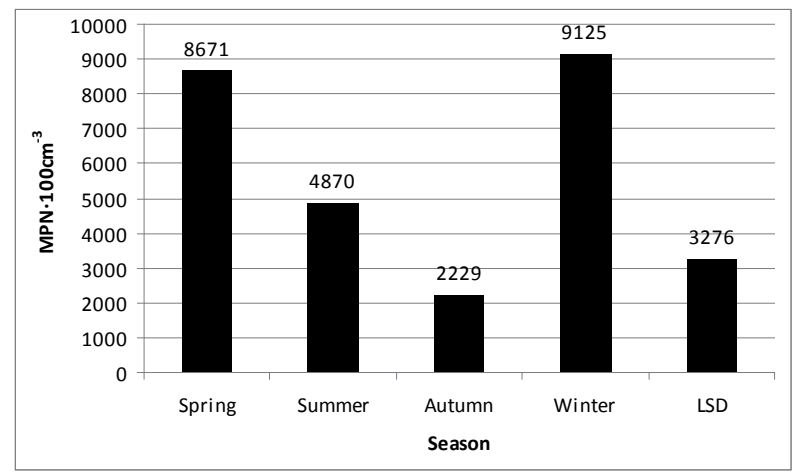

Fig. 5. The medium MPN of fecal coliform bacteria depending on the season in 2003-10.

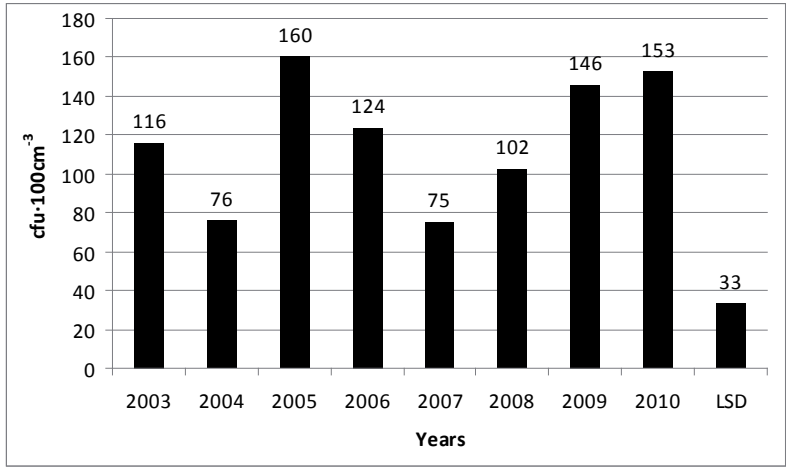

Fig. 6. The average number of Enterococcus faecalis in 2003-10.

showed their largest number in the winter months $\left(9,125 \mathrm{MPN} 100 \mathrm{~cm}^{-3}\right)$, and slightly lower in the spring months $\left(8,671 \mathrm{MPN} 100 \mathrm{~cm}^{-3}\right)$. The smallest number of thermo-tolerant coliforms occurred in autumn $(2,229$ MPN $100 \mathrm{~cm}^{-3}$ ), while more than twice during the summer $\left(4,870 \mathrm{MPN} 100 \mathrm{~cm}^{-3}\right)$ (Fig. 5). Similar occurrences of these bacteria were noted by Vereen et al. [31] in waters of the upper portions of the Satilla River in Georgia.

Changes in the amount of thermo-tolerant coliform bacteria depending on the $\mathrm{pH}$ of water were not analyzed due to the small number of such tests resulting from legal circumstances.

\section{Fecal Enterococci}

The average number of fecal enterococci ranged from $75 \mathrm{cfu} 100 \mathrm{~cm}^{-3}$ (2007) to $160 \mathrm{cfu} 100 \mathrm{~cm}^{-3}$ (2005) (Fig. 6). The smallest number of fecal enterococci was detected in summer 2007: $29 \mathrm{cfu} 100 \mathrm{~cm}^{-3}$, whereas the highest were in spring $2006\left(210 \mathrm{cfu} 100 \mathrm{~cm}^{-3}\right)$. Such an abundance of fecal enterococci detected in waters of the Wisłoka allow for classification of these waters to the second category of surface water used for public supply for consumption with a maximum permissible value of $1,000 \mathrm{cfu} 100 \mathrm{~cm}^{-3}$ (Reg. Min. Environ. .... 2002). Donderski [32] reported similar amounts of fecal enterococci in surface waters of the Vistula River.

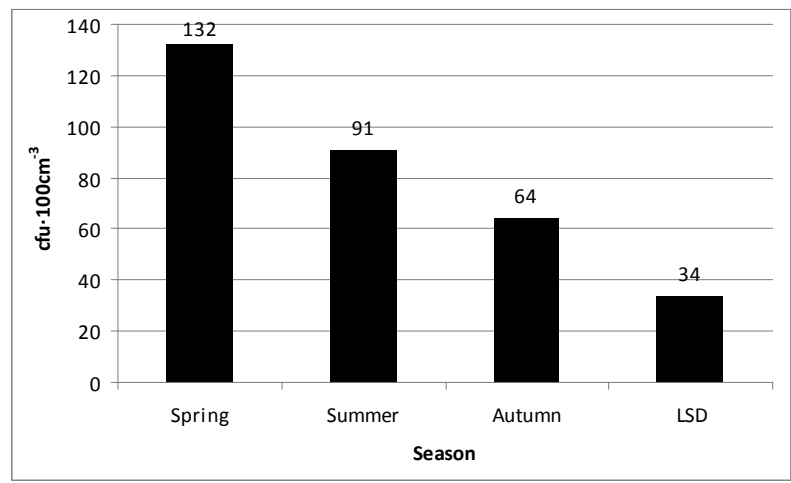

Fig. 7. The average number of Enterococcus faecalis depending on the season in 2003-10. 
Table 2. Number of faecal coliform bacteria Enterococcus faecalis and their interrelation in the water of the Wisloka River.

\begin{tabular}{|c|c|c|c|c|}
\hline \multirow{2}{*}{ No. } & Years of research & Fecal coliform bacteria (FC) & Enterococcus faecalis (EF) & FC/EF \\
\cline { 2 - 5 } & Unit & MPN·100 $\mathrm{cm}^{-3}$ & MPN·100cm & - \\
\hline 1 & 2003 & 2493 & 116 & 21.49 \\
\hline 2 & 2004 & 16233 & 76 & 77.59 \\
\hline 3 & 2005 & 12350 & 160 & 0.23 \\
\hline 4 & 2006 & 29 & 124 & 85.81 \\
\hline 5 & 2007 & 6436 & 75 & 35.49 \\
\hline 6 & 2008 & 3620 & 102 & 47.94 \\
\hline 7 & 2009 & 7000 & 146 & 20.92 \\
\hline 8 & 2010 & 3200 & 153 & 55.79 \\
\hline
\end{tabular}

Ratio: FC/EF $>4$ human origin

$\mathrm{FC} / \mathrm{EF}<0.7$ animal origin

Presented data indicate (Fig. 7) that there are different average numbers of fecal enterococci at particular seasons of the year. Statistically significant differences were found between the presence of these microorganisms in spring and summer as well as between spring and autumn, when their average number in water was the lowest. Fecal enterococci were not studied in winter. Studies upon waters of rivers in Podkarpacie province [8] reveal that the amounts of pathogenic microorganisms in winter and spring are much higher than in summer, which is reflected in the test results referring to water from the Wisłoka. This is probably related to the low water levels during winter at the large inflow of sewage containing Enterococcus faecalis [22]. In the summertime there is also significant insolation and, as noted by Davies et al. [33], the solar radiation inactivates bacteria (including Enterococcus faecalis).

Microbiological indicators presented in this study inform not only about the scale, but also the source of contamination (Table 2). However, the number of fecal bacteria (thermo-tolerant coliform bacteria, and Enterococcus faecalis) is a more precise indicator, which shows the microbiological contamination originated from human or animal waste [34]. Moreover, according to some authors [35-38], the ratio of total thermo-tolerant coliforms to Enterococcus faecalis bacteria may be crucial for the accurate assessment of the type (origin) of contamination. Data presented in Table 2 show that in almost all years of study (with the exception of 2006), the ratio amounted to $>4$. Such value of this parameter indicates that human contamination exerted the main impact on the sanitary condition of water. Only in 2006 was the ratio 0.23 , which indicates that during this period microbiological contaminants were zoonotic in nature. Similar conclusions were also drawn by other authors [32], who in the research upon sanitary condition of the Vistula also used the abovementioned microbiological indicators.

\section{Salmonella}

In the period 2005-2010, nearly 60 water samples from river Wisłoka at the point of water intake for the residents of Mielec, were also examined for the presence of pathogenic bacilli of Salmonella genus. However, none of the tests did not reveal the presence of this microorganism in tested waters. The presence of Salmonella was not find per $1000 \mathrm{~cm}^{-3}$, which allowed to qualify the water of river Wisłoka (taking into account this sanitary parameter) to A2 category in accordance with Reg. Min. Environ. ... 2002 [21]. From literature review of this scope follows, that the other authors, that stated presence of Salmonella pathogens, also found, that it was linked with rainfall quantity [17, 30, 31]. Vereen et al. [31] emphasized that Salmonella detection frequency was inversely related to the total rainfall. Sigua et al. [17] showed that concentrations fecal coliforms, E. coli, and Salmonella in water samples were higher during wet months than during dry months.

\section{The Correlation between Analyzed Microbiological Parameters and Selected Variables of Water Quality}

Correlation coefficients between microbiological parameters depending on the properties determining the quality of surface water were also calculated, which are shown in Table 3. The present microbiological studies in this part of the article are the biggest part of a wide body of work dedicated to Wisłoka water quality in the area of Mielec, and they have complied with physicochemical parameters presented in previous studies.

Most of the physicochemical indicators that characterize Wisłoka waters had a slight or weak influence on the quantitative presence of studied pathogenic microorganisms (Table 3). Based on studies of the Tamiraparani River catchment, Sivanandham et al. [39] also found that microbial-contaminated communities 
Table 3. The correlation coefficients between the analyzed microbiological parameters depending on selected properties determining Wisłoka water quality.

\begin{tabular}{|c|c|c|c|c|}
\hline No. & Indicator & Coliform bacteria & Fecal coliform bacteria & Enterococcus faecalis \\
\hline $\mathrm{N}$ & Number of samples & 129 & 85 & 85 \\
\hline 1 & Temperature & $-0.21 *$ (low) & $-0.16^{*}$ (low) & -0.05 (faint) \\
\hline 2 & Odor & -0.09 (faint) & n.c. & n.c. \\
\hline 3 & Color & -0.07 (faint) & -0.15 (low) & $-0.34 *$ (average) \\
\hline 4 & Turbidity & -0.08 (faint) & n.c. & n.c. \\
\hline 5 & $\mathrm{pH}$ & -0.08 (faint) & n.c. & n.c. \\
\hline 6 & Dry residue & 0.12 (low) & n.c. & n.c. \\
\hline 7 & Oxidation & $-0.14 *$ (low) & n.c. & n.c. \\
\hline 8 & Dissolved oxygen & $0.23 *$ (average) & n.c. & n.c. \\
\hline 9 & $\mathrm{BOD}_{5}$ & $0.17 *$ (low) & -0.11 (low) & $0.85^{*}$ (very high) \\
\hline 10 & Specific electrical conductivity & $0.78 *$ (very high) & $0.70 *$ (very high) & 0.15 (low) \\
\hline 11 & Alkalinity & -0.02 (faint) & n.c. & n.c. \\
\hline
\end{tabular}

* - statistically significant values (significance level $\mathrm{p}=0,05$ );

n.c. - not calculated

were not associated with geochemical parameters too. Depending on the dissolved oxygen content and number of coliform - for which a positive correlation was found as well as between fecal enterococci number and color of the water - average correlation was shown. A very high positive correlation was recorded between the presence of coliform bacteria and thermo-tolerant coliforms vs. specific electrical conductivity of water samples (at the level of 0.78 and 0.70 , respectively). The highest correlation coefficient $(0.85)$ was found between the amount of fecal enterococci and $\mathrm{BOD}_{5}$ indicator. Very high correlation between these water parameters confirms the general relationship between the increase in water contamination and the number of microorganisms, and increasing the rate of biochemical oxygen demand.

\section{Conclusions}

1. In the study period (1999-2010), the average number of coliforms and thermo-tolerant coliforms in Wisłoka water, derived from the water intake point for Mielec, oscillated within a wide range while maintaining a downward trend. During the study, water quality was good. However, occasionally the test sanitary parameters excluded water from the Wisłoka from its supply to thevpublic as drinking water.

2. The average number of fecal enterococci (Enterococcus faecalis) varied over the study period at a fixed tendency of their occurrence growth. These numbers did not exceed the standards for surface waters defined in the regulation from 2002.

3. Within many years of research, the main impact on the sanitary condition of the surface water in Wisłoka was exerted by human-origin contamination. Only in 2006 was there pollution of a zoonotic nature.

4. Pathogenic Salmonella was not found in Wisłoka waters in the study period (2005-10).

5. Analyzed sanitary parameters of Wisłoka surface water from the water intake for Mielec were highly variable, depending on the season, and sometimes on the $\mathrm{pH}$ of the water.

6. Very high, positive correlation $\left(r_{x, y} \geq 0.7\right)$ between the specific electrolytic conductivity of water and the number of coliform bacteria and thermo-tolerant coliform was recorded. Very high positive correlation $\left(r_{x, y}=0.85\right)$ was also revealed between $\mathrm{BOD}_{5}$, and fecal enterococci numbers.

\section{References}

1. AUGUSTYN Ł., KANIUCZAK J., STANEK-TARKOWSKA J. Selected physicochemical and chemical properties of surface water of Wisloka for consumption. Ecol Eng. 28, 7-20, 2012 [in Polish].

2. DELPLA I., RODRIGUEZ M.J. Effects of future climate and land use scenarios on riverine source water quality, Science of The Total Environment. 493, 1014, 2014, doi:10.1016/j. scitotenv.2014.06.087.

3. JAROŃ-WARSZYŃSKA R., NAWROT J., SIKORA A. Surface water protection. In: Environment condition in Podkarpacie Province in 2001. WIOŚ in Rzeszow. BMŚ. 53, 2002 [In Polish].

4. GRAVES A.K, WEAVER R.W. Characterization of enterococci populations collected from a subsurface flow constructed wetland. J Appl Microbiol. 108 (4), 1226, 2010, doi:10.1111/j.1365-2672.2009.04516.x.

5. HAGENDORF U., DIEHL K., FEUERPFEIL I., HUMMEL A. SZEWZYZK R. Retention of microbiological organisms in constructed wetlands. In: Proceedings of the Seventh International Conference on Wetland Systems for Water Pollu- 
tion Control., Gainesville: IWA and University of Floryda, 391, 2000.

6. JOKINEN C.C., EDGE T.A., KONING W., LAING C.R., LAPEN D.R., MILLER J., et al. Spatial and temporal drivers of zoonotic pathogen contamination of an agricultural watershed. J Environ Qual. 41 (1), 242, 2012, doi:10.2134/ jeq2011.0203.

7. PRATT B., CHANG H. Effects of land cover, topography, and built structure on seasonal water quality at multiple spatial scales. J Hazard Mater. 209, 48, 2012, doi:10.1016/j. jhazmat.2011.12.068.

8. WALCZAK M., Changes of microbial indices of water quality in the Vistula and Brda rivers as a result of sewage treatment plant operation. Oceanol. and Hydrobiol. Studies. XXXVII (2), 65, 2008, doi: 10.2478/v10009-007-0049-7.

9. AHMEDW., SAWANT S., HUYGENSF., GOONETILLEKE A., GARDNER T. Prevalence and occurrence of zoonotic bacterial pathogens in surface waters determined by quantitative PCR. Water Research. 43 (19), 4918, 2009.

10. SHELLENBARGER G.G., ATHEARN N.D., TAKEKAWA J.Y., BOEHM A.B. Fecal indicator bacteria and Salmonella in ponds managedas bird habitat, San Francisco Bay. California, USA. Water Research. 42, 2921, 2008, doi:10.1016/j. watres.2008.03.006

11. FIELLO M., MIKELL JR. A.T., MOORE M.T., COOPER C.M. Variability in the Characterization of Total Coliforms, Fecal Coliforms and Escherichia coli in Recreational Water Supplies of North Mississippi, USA. Bulletin of Environmental Contamination and Toxicology. 93 (2), 133, 2014, doi:10.1007/s00128-014-1299-1.

12. FIGUREAS M.J, BORREGO J.J. New perspectives in monitoring drinking water microbial quality. Int J Environ Res Public Health. 7, 4179, 2010, doi:10.3390/ijerph7124179.

13. FRĄK M., Escherichia coli as a potential indicator of Biebrza River enrichment sources. Journal of Water and Land Development. 19, 31, 2013, doi: 10.2478/jwld-2013-0013.

14. ROMPRE A., SERVAIS P., BAUDART J., DE-ROUBIN M., R., LAURENT P. Detection and enumeration of coliforms in drinking water: current methods and emerging approaches. J Appl Microbiol. 49 (1), 31, 2002, doi: 10.4269/ajtmh.13-0349.

15. TALLON P., MAGAJNA B., LOFRANCO C., LEUNG K.T. Microbial indicators of faecal contamination in water: a current perspective. Water Air Soil Poll. 166 (1-4), 139, 2005, doi:10.1007/s11270-005-7905-4.

16. VYMAZAL J. Removal of enteric bacteria in constructed treatment wetlands with emergent macrophytes; a review. J Environ Sci Heal A. 40 (6-7), 1355, 2005. doi: 10.1081/ESE200055851

17. SIGUA G.C., PALHARES J.C.P., KICH J.D., MULINARI M.R., MATTEI R.M., KLEIN J.B., MULLER S., PLIESKE G. Microbiological Quality Assessment of Watershed Associated with Animal-Based Agriculture in Santa Catarina, Brazil. Water Air Soil Pollut. 210, 307, 2010. doi: 10.1007/ s11270-009-0254-y.

18. FISHER K., PHILLIPS C. The ecology, epidemiology and virulence of Enterococcus. Microbiology. 155, 1749, 2009, doi:10.1099/mic.0.026385-0.

19. SALYERS A.A, WHITT D.D. Microbes and a human in imbalance: infectious diseases. In: Microbiology. Diversity, pathogenicity and environment. PWN, Warsaw, 2012 [In Polish].

20. Council Directive 75/440/EEC of 16 June 1975 concerning the quality required of surface water intended for the abstraction of drinking water in the Member States. http://eur-lex. europa.eu/legal-content/EN/TXT/?uri=URISERV:128006a, 2007.
21. Environment Ministry Regulation of 27.11.2002 on the requirements that should be met by surface waters used to supply population in consumption water (J. L. No 204, pos. 1728), 2002, [In Polish].

22. ZAWADA A. General geographic and economic characteristic Podkarpacie Province. In: Environment condition in Podkarpacie Province in 2001. WIOŚ in Rzeszow. BMŚ. 9, 2002, [In Polish].

23. KANIUCZAK J., AUGUSTYN $€$. The content of nitrogen compounds and phosphates in surfaces water intended for supply in drinking water. Ecol Eng. 27, 46, 2011, [In Polish].

24. Environment condition in Podkarpackie Province in years 1999-2008. WIOŚ in Rzeszow. BMŚ, 48, 2009, [In Polish].

25. SKONIECZEK P. Water hazards in rural areas. In: Water resources and quality protection in rural landscape. Olsztyn: Contemp. Probl. of Devel. and Environ. Prot. 87, 2011, [In Polish].

26. FONSECA A., BOTELHO C., BOAVENTURA R.A.R., VILAR V.J.P. Integrated hydrological and water quality model for river management: A case study on Lena River. Science of The Total Environment. 485, 474, 2014, doi:10.1016/j. scitotenv.2014.03.111.

27. STARADUMSKYTĖ D., PAULAUSKAS A. Indicators of microbial drinking and recreational water quality. Biologija. 58 (1), 7, 2012.

28. GRABIŃSKA B. Changes in river water quality on the background of natural diversity conditions and catchment usage. In: Water resources and quality protection in rural landscape. Contemp. Probl. of Devel. and Environ. Prot. Olsztyn, 223, 2011 [In Polish].

29. KADIR K., NELSON K.L. Sunlight mediated inactivation mechanisms of Enterococcus faecalis and Escherichia coli in clear water versus waste stabilization pond water. Water Research. 50, 307, 2014, doi:10.1016/j.watres.2013.10.046.

30. HEMA C., NAIR D., PADMALAL A.J. Hydrochemical assessment of tropical springs - a case study from SW India. Environmental Monitoring and Assessment. 187, 48, 2015, doi:10.1007/s10661-014-4164-0.

31. VEREEN JR. E., LOWRANCE R.R., JENKINS M.B, ADAMS P., RAJEEV S., LIPP E.K. Landscape and seasonal factors influence Salmonella and Campylobacter prevalence in a rural mixed use watershed. Water Research. 47 (16), 6075, 2013, doi:10.1016/j.watres.2013.07.028.

32. DONDERSKI W., WILK I. The Sanitary State of Water the River Vistula between Wyszogrod and Torun. Polish J Environ Stud. 11, 509, 2002.

33. DAVIES C.M., ROSERA D.J., FEITZA A.J., ASHBOLT N.J. Solar radiation disinfection of drinking water at temperate latitudes: Inactivation rates for an optimised reactor configuration. Water Research. 43 (3), 643, 2009, doi:10.1016/j.watres.2008.11.016.

34. Department of the Environment, The Microbiology of Drinking Water - Water Quality and Public Health, Part 1, 2002.

35. GELDREICH E.E. Applying bacteriological parameters to recreational water quality. J Am Water Works Ass. 62, 113, 1970.

36. NIEWOLAK S. The evaluation of the contamination degree and the sanitary and bacteriological state of the waters in the Czarna Hancza River in the region of Suwalki and the Wigry National Park. Polish J Environ Stud. 7, 229-241, 1998.

37. WALTERS S.P., THEBO A.L., BOEHM A.B. Impact of urbanization and agriculture on the occurrence of bacterial pathogens and stx genes in coastal waterbodies of central California. Water Research. 45 (4), 1752, 2011, doi:10.1016/j.watres.2010.11.032. 
38. ZIEMIŃSKA S., MALESZEWSKA J., MILKOWSKAJANKOWSKA D., HAMAN S. Fecal streptococci as indicators of fecal water contamination. III. Occurrence of fecal streptococci, coli group bacteria and fecal coliforms in water. Roczn PZH. 31 (5), 519, 1980.
39. SIVANANDHAM V., HANS-UWE D., PERIYASAMY K., ANNAMALAI R., BONG-RAE K., RATHINAM A.J. Microbial Effects on Geochemical Parameters in a Tropical River Basin. Environmental Processes. 2 (1), 125, 2015, doi:10.1007/s40710-015-0058-6. 
